\title{
ArcheoSciences
}

Revue d'archéométrie

\section{Early Medieval stronghold Libice nad Cidlinou. An example of use of geophysical methods in systematic non-destructive archaeological project}

\section{Roman Křivánek and Jan Mařík}

\section{OpenEdition}

\section{Journals}

Electronic version

URL: https://journals.openedition.org/archeosciences/1349

DOI: 10.4000/archeosciences. 1349

ISBN: 978-2-7535-1599-4

ISSN: $2104-3728$

Publisher

Presses universitaires de Rennes

\section{Printed version}

Date of publication: 30 October 2009

Number of pages: $93-95$

ISBN: 978-2-7535-0943-6

ISSN: $1960-1360$

\section{Electronic reference}

Roman Křivánek and Jan Mařík, "Early Medieval stronghold Libice nad Cidlinou. An example of use of geophysical methods in systematic non-destructive archaeological project", ArcheoSciences [Online], 33 (suppl.) | 2009, Online since 30 October 2011, connection on 21 September 2021. URL: http:// journals.openedition.org/archeosciences/1349 ; DOI: https://doi.org/10.4000/archeosciences.1349 


\title{
Early Medieval stronghold Libice nad Cidlinou An example of use of geophysical methods in systematic non-destructive archaeological project
}

\author{
Roman KřIVÁNeK* and Jan MAŘíK*
}

Key words: Magnetometric survey, Non-destructive archaeology, Stronghold, Early Medieval settlement, Fortification.

\section{SITE DESCRIPTION}

The early medieval stronghold Libice nad Cidlinou is one of the most important sites for the beginnings of the Czech state. It is situated in the lowlands of Central Bohemia (60 km east of Prague). This type of large early medieval stronghold (approx. $25 \mathrm{ha}$ ) is a rare kind of site in Bohemian archaeology. It was built on remnants of a sand-gravel terrace (two islands), naturally protected by the surrounding floodplain and the meanders of the river Cidlina (Fig. 1). The inner bailey (so-called acropolis, approx. $11.5 \mathrm{ha}$ ) is still ploughed agricultural land. A regular excavation focused mainly on the eastern part of the inner bailey discovered remains of an early medieval church, part of a large graveyard (288 graves) and remains of a ducal palace. The original outer bailey (approx. 14.6 ha) was remodelled later by settlement in medieval and modern times and it is now covered by the modern village of Libice nad Cidlinou.

\section{Site ARCHAEOLOGY}

The first systematic archaeological research started at the inner bailey after WW II (1948-53, 1967-73). Archaeological excavations inside the area of the outer bailey and the rest of the modern village of Libice have been underway since 1974. The oldest settlement on the lowland terraces along the lower Cidlina River can be dated to the late Bronze Age and the Roman period. The first Slavic settlement in this area (outer bailey) started in the 6th century. The beginnings of the early medieval centre in Libice reach back to as far as the turn of the 10th century. Libice of the 10th century is assumed to have been the centre of the Slavník family's domain. The most famous member of the Slavníks was probably the second bishop of Prague, St. Adalbert. Bohemian duke Boleslav II put an end to the family's importance, killing most of its members on 28 September 995. In the 11th and 12 th centuries, Libice became part of the administration system of the Přemyslid dukes. The stronghold went out of use in the second half of the 12th century, but settlement has continued in the outer bailey ever since.

\section{ArChaEOlogical PROJECT}

The present archaeological project supported by the Grant Agency of the Academy of Sciences of the Czech Republic, "The inner bailey of the Libice stronghold - of the possibi-

* Institute of Archaeology of the Academy of Sciences of the Czech Republic, Prague, v. v. i., Letenska 4, 11801 Prague 1, Czech Republic. (krivanek@ arup.cas.cz) (marik@arup.cas.cz) 


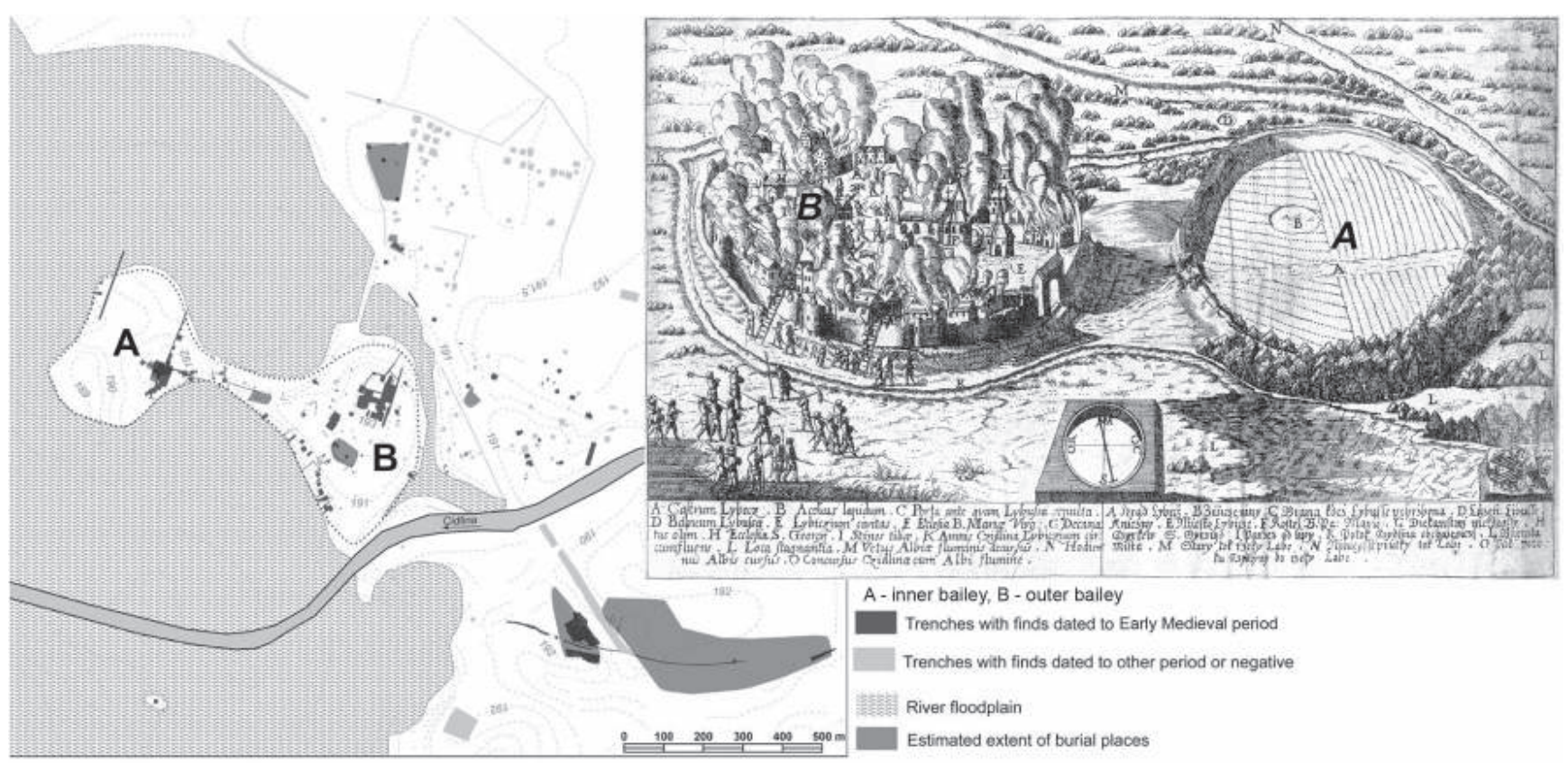

Figure 1: Libice nad Cidlinou: Early Medieval stronghold agglomeration (on the left), Libice around the year 1668. After: M. B. Bolelucký, Rosa Boemica sivr Vita sancti Woytiechi agnomine Adalberti Pragensis episcopi Vngariae Poloniae Prussiae apostoli, Praha 1668 (on the right).

lities of non-destructive archaeology and modern technology in the process of the study of archaeological sources" (KJB800020803, Mařík et al. 2008-2010) offers new possibilities for interdisciplinary cooperation in the study of the central (still open and mainly ploughed) bailey of the stronghold. A comprehensive non-destructive survey of this area is based on a combination of aerial prospection (Fig. 2), geophysical surveys together with surface collection and results of archaeological excavations. Through modern GIS application these results can be made to tell more about the site, distinguishing subsurface remains of various activities (probable settlement, funeral area, communication paths, fortification, gates, production places...), as well as defining directions for future archaeological research. Cooperation with another archaeological project supported by the Grant Agency of the Czech Republic, "The hinterland of the early medieval centre - the economic system" (404/08/1696, Maŕík et al. 2008-2010), permits the archaeological site to be observed on a much broader scale in relation to other early medieval sites on the microregional level.

\section{RESULTS OF GEOPHYSICAL SURVEY}

The entire inner bailey of the Libice stronghold (approx. 11 ha) has been surveyed geophysically between 2008 and
2010 with a gradient caesium magnetometer (Smartmag SM-4g, Scintrex) with density approx. $1 \times 0.2-0.25 \mathrm{~m}$. Selected areas of particular archaeological value will be surveyed by the same method in greater detail, approx. 0.5 $\mathrm{x} 0.2 \mathrm{~m}$. Places with possible continuity of stone remains (the ramparts or the area next to the early medieval church and palace) will also be surveyed by the geoelectric resistivity method in $0.5 \times 0.5 \mathrm{~m}$ scale. For all of the geophysical measurements, the same N-S oriented grid net, which will also be used for subsequent surface collection and for metal detector surveys, will be applied.

The results of the magnetometric survey (combined with density of archaeological finds and intensity of vegetation changes observed in aerial photos) proved that the whole inner bailey was the site of intensive settlement (Fig. 3). There are some differences in density of the identified buried settlement features on the site: larger features concentrated in separate groups and possible linear remains of buried features in other areas that could indicate a more structured settlement inside the stronghold. Some parts appear to include production features (furnaces or remains of burned material). The magnetometric survey also brought new information about the fortification system. Historical records maintain that the stronghold was burned down in a conflagration at the end of the 10th century, but the magnetometric results indicate only parts of this perimeter 


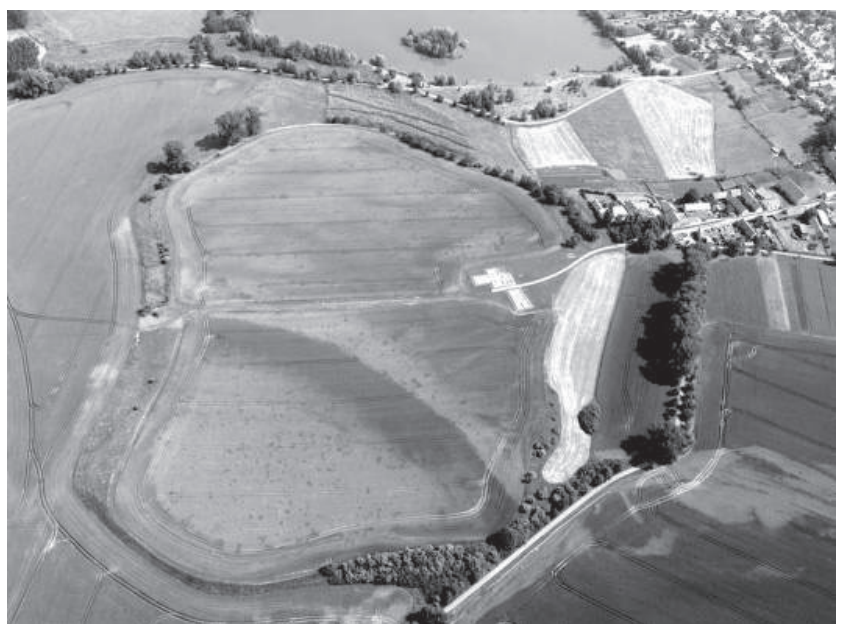

Figure 2: Aerial prospection of the Libice stronghold with evidence of intensive settlement (Gojda 2007).

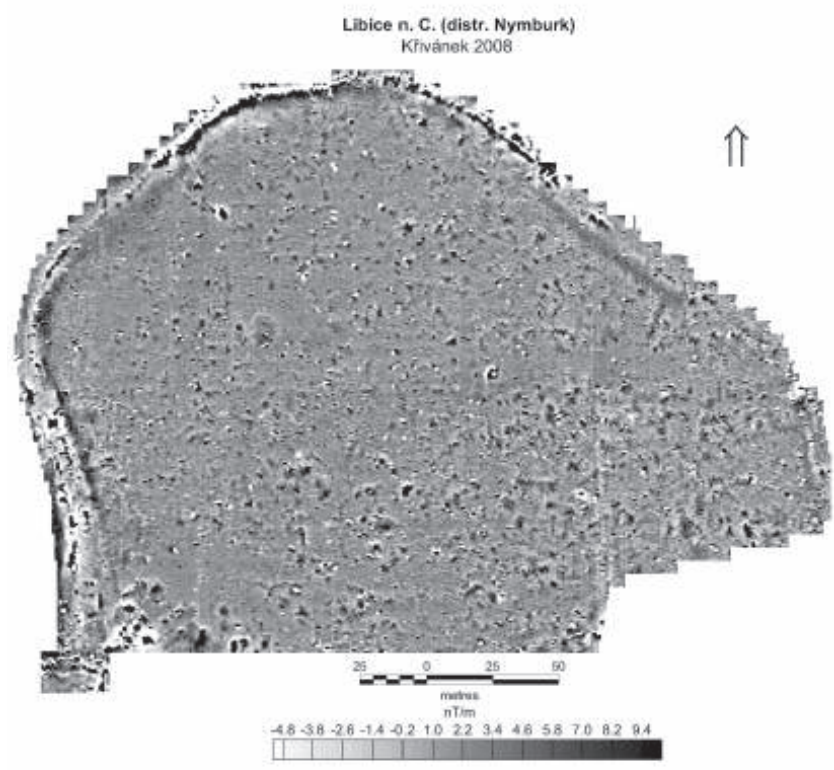

Figure 3: Identification of intensive settlement and remains of the enceinte walls in the magnetometric mapping of the northern half of the stronghold (surveyed area approx. 5.5 ha, Křivánek 2008).

fortification suffering damages. The identified remains of an inner ditch and a turn in the line of the wall could also indicate some internal communication or a previously unknown entrance to the stronghold.

\section{USE OF GEOPHYSICAL RESULTS}

Field data from GIS magnetometric and resistivity surveys can be used in combination with, for example, density and concentration of various archaeological finds (ceramics, slag, stone remains etc.) and vegetation changes (buried features) visible in aerial photographs. New data supplied by nondestructive archaeological investigations in the central area of the stronghold can be combined and locally verified with the results of earlier archaeological excavations. We hope this opportunity for collecting comprehensive evidence by non-destructive methods will enhance the archaeological interpretation of identified features and evaluate the subsurface state of preservation of a protected archaeological monument. 